\title{
Short communication: Timing of first milking affects serotonin (5-HT) concentrations
}

\author{
J. Laporta, ${ }^{\star}$ J. J. Gross,† T. D. Crenshaw,‡ R. M. Bruckmaier, † and L. L. Hernandez ${ }^{\star 1}$ \\ *Department of Dairy Science, University of Wisconsin, Madison 53706 \\ †Veterinary Physiology, Vetsuisse Faculty, University of Bern, CH-3001 Bern, Switzerland \\ ‡Department of Animal Sciences, University of Wisconsin, Madison 53706
}

\section{ABSTRACT}

Hormonal signals differentially regulate the timing of parturition, as well lactogenesis and, potentially, colostrum formation in the mammary gland. Non-neuronal serotonin (5-HT) is a homeostatic regulator of the mammary gland. In the current study, we manipulated the timing of first milking to investigate its effects on serum 5-HT and calcium concentrations in the maternal and calf circulation, as well as in colostrum. Twenty-three cows were randomly assigned to a control $(\mathrm{CON} ; \mathrm{n}=$ 10) group, milked for the first time at $4 \mathrm{~h}$ postcalving, or a treatment (TRT; $\mathrm{n}=13$ ) group, milked for the first time approximately $1 \mathrm{~d}$ before calving in addition to 4 $\mathrm{h}$ postcalving. Maternal blood samples were collected for $4 \mathrm{~d}$ precalving, 3 times daily, and 1 blood sample was taken $4 \mathrm{~h}$ postcalving. Calf blood samples were collected 4 (before first colostrum feeding) and $12 \mathrm{~h}$ after birth, and at 3 wk of age. Calves from both treatments were fed colostrum from their respective mothers. Serum 5-HT concentrations were greater in $\mathrm{CON}$ cows and decreased significantly in TRT cows after milking was initiated precalving (951 vs. $524 \pm 111 \mathrm{ng} / \mathrm{mL}$, respectively). Cow serum calcium concentrations were affected by time, beginning to decrease $1 \mathrm{~d}$ precalving until $4 \mathrm{~h}$ postcalving, but this drop in serum calcium was more pronounced in TRT cows. Serum 5-HT and calcium concentrations were negatively correlated $(\mathrm{r}=$ $-0.57)$ for the CON cows and positively correlated ( $\mathrm{r}$ $=0.6)$ for the TRT cows. Maternal calcium and 5-HT decreased similarly due to precalving milking. Calcium and 5-HT concentrations were greater in colostrum collected from TRT cows milked precalving. Overall, calves had higher circulating 5-HT concentrations than cows, and calves born to TRT cows had increased 5-HT concentrations compared with the CON. Precalving milking could affect 5-HT synthesis within the mammary gland and therefore affect maternal 5 - $\mathrm{HT}$ and calcium concentrations. Further research is needed in

Received August 5, 2013.

Accepted January 30, 2014

${ }^{1}$ Corresponding author: llhernandez@wisc.edu ruminants to assess the extent of 5-HT placental transfer, its role on pre- and postnatal development of the calf, the importance of its presence in colostrum, and potential long-term effects on calf health.

Key words: colostrum, serotonin, precalving milking, calcium

\section{Short Communication}

Several endocrine and metabolic signals differentially regulate the mammary gland at the time of parturition, in addition to having effects on lactogenesis and, potentially, colostrum formation in the mammary gland. Prepartum milking has been used to reduce udder pressure, to prevent the development of mastitis, and to modulate metabolism or physiology to reduce the incidence of milk fever (Bowers et al., 2006; Rastani et al., 2007; Kronqvist et al., 2014).

Serotonin (5-hydroxytryptamine; $\mathbf{5 - H T}$ ) is a monoamine synthesized from the amino acid L-tryptophan. In the brain (neuronal 5-HT), it mediates a wide range of central nervous system functions (Berger et al., 2009), but it is also synthetized in various tissues throughout the body (non-neuronal 5-HT) and exerts its physiological actions by signaling through approximately 15 different receptor subtypes (Hannon and Hoyer, 2008; Berger, 2009). Non-neuronal 5-HT was reported to be a novel homeostatic regulator of the mammary gland (Collier et al., 2012). Particularly, it is involved in the regulation of milk protein synthesis (Matsuda et al., 2004; Hernandez et al., 2011), cell apoptosis, and regulation of tight junctions (Matsuda et al., 2004; Stull et al., 2007; Pai and Horseman, 2008). Additionally, 5-HT was induced by milk stasis in a rodent model (Matsuda et al., 2004). Furthermore, our laboratory recently demonstrated the involvement of 5-HT in calcium and glucose metabolism in animals transitioning from pregnancy to lactation (Hernandez et al., 2012; Laporta et al., 2013a,b). The bovine mammary gland possesses five 5-HT receptor subtypes, suggesting dynamic regulation of the mammary gland by 5-HT (Hernandez et al., 2009). Specifically, 5-HT signaling via the 5-HT7 receptor subtype regulates mammary gland involution 
through alterations in tight junctions, and the 5-HT2B receptor subtype is involved in modulation of calcium homeostasis (Stull et al., 2007; Pai and Horseman, 2008; Hernandez et al., 2012).

Due to the role of 5-HT in regulating several aspects of lactation and mammary gland physiology, and its involvement in calcium homeostasis, we hypothesized that timing of first milking could potentially affect circulating and colostrum 5-HT concentrations and consequently affect calcium metabolism of the cow. Therefore, our objective was to investigate the effect of timing of first milking (pre- vs. postcalving) on 5-HT and ionized calcium concentrations in the circulation of the cow. Additionally, we were interested in the effects on concentrations of 5 -HT and total calcium in colostrum and its possible effect on the calf.

We conducted the current study to determine whether precalving milking affects calcium and 5-HT metabolism in dairy cows. The experiment was performed at the Research Station in Posieux, Switzerland. All protocols were approved by the Veterinary Office of the Canton of Fribourg (permit number 2011-40-FR). Twenty-three multiparous Holstein cows (lactation number $3.6 \pm 0.4$ ) were assigned to 2 groups according to previous lactation yield: a control $(\mathbf{C O N} ; \mathrm{n}=10)$ group that was milked for the first time $4 \mathrm{~h}$ postcalving and a treatment (TRT; $\mathrm{n}=13$ ) group that was milked for the first time (only once precalving) approximately $1 \mathrm{~d}$ before calving [when the mammary gland seemed to have sufficient milk for the calf $(\sim 2 \mathrm{~kg})]$ and again at 4 $\mathrm{h}$ postcalving. During the dry period until calving, cows were fed hay plus $1 \mathrm{~kg}$ of a cereal-based concentrate and $0.5 \mathrm{~kg}$ of a mineral supplement at a rate to allow ad libitum intake. Feed intake was not recorded and no samples were taken from the diets. Approximately 1 wk before expected parturition, cows were moved from the freestall barn to individual calving pens and blood sampling began. Maternal blood samples were collected from the jugular vein for $4 \mathrm{~d}$ precalving, 3 times daily at 0600,1400 , and $2200 \mathrm{~h}$, and 1 blood sample was taken $4 \mathrm{~h}$ after parturition (before milking). Calves were weighed and separated from the dam immediately after birth. Colostrum samples were collected from the entire udder. Calf blood samples were collected at $4 \mathrm{~h}$ after birth (before first colostrum feeding), $12 \mathrm{~h}$ after birth, and at 3 wk of age. Calves were fed $2 \mathrm{~kg}$ of colostrum from their respective mothers at $4 \mathrm{~h}$ postcalving. Blood samples were allowed to clot for $30 \mathrm{~min}$ before centrifugation $\left(2,500 \times g\right.$ for $15 \mathrm{~min}$ at $\left.4^{\circ} \mathrm{C}\right)$ to harvest serum. Serum and colostrum were subsequently stored at $-80^{\circ} \mathrm{C}$ until analysis.

For all the assays performed, samples were randomized and a quality control was analyzed on each plate to ensure assay accuracy and consistency. Serotonin concentrations in serum and colostrum samples were measured using a Serotonin ELISA Fast Track (KG \#BA E-8900; Rocky Mountain Diagnostics, Colorado Springs, CO) commercial kit according to the manufacturers' instructions. The intraassay CV was less than $4.9 \%$ and the interassay CV was less than $14.5 \%$ for serum and colostrum 5-HT. Serum calcium concentrations were measured with a colorimetric calcium assay kit (\#700550; Cayman Chemical Company, Ann Arbor, MI) according to the manufacturer's instructions; the intraassay CV was $4.8 \%$ and the interassay CV was $6.1 \%$. Total colostrum calcium was measured by atomic absorption spectrophotometry procedures as described in Rortvedt and Crenshaw (2012), with the addition of a hydrochloric acid digestion step (Perkin-Elmer Model 2280, Perkin-Elmer Corp., Norwalk, CT); the intraassay CV was $2.3 \%$. Data were analyzed using the SAS Systems program (SAS 9.3V, SAS Institute Inc., Cary, NC). Cow serum 5-HT and ionized calcium, as well as calf serum 5-HT data were analyzed as repeated measures using the MIXED procedure with cow or calf number serving as the random effect, the autoregressive covariance structure AR(1), and the Kenward-Rogers procedure. The UNIVARIATE procedure was used to identify outliers and verify normality of residuals. Nonparametric RANK test was applied due to lack of normality of the data. Serotonin and total calcium concentrations in colostrum were analyzed using the TTEST procedure. Correlation coefficients to describe relationships between 5 -HT and calcium variables were estimated using the CORR procedure. For all analyses, differences between means were considered significant at $P \leq 0.05$. All values are reported as means \pm SEM.

Circulating 5-HT concentrations were significantly higher in CON compared with TRT cows (951 vs. 524 $\pm 111 \mathrm{ng} / \mathrm{mL}$, respectively; $P=0.01$ ) throughout the study. Serotonin concentrations significantly decreased in the TRT cows after milking was initiated precalving and continued to decrease, compared with the CON cows, in which concentrations increased significantly $(P<0.02$; Figure $1 \mathrm{~A})$. Precalving milking did not affect cow serum calcium concentrations $(P>0.05)$, but was affected by time $(P<0.0001)$ and a treatment by time interaction $(P<0.04$; Figure 1B). Serum calcium concentrations began to decrease $1 \mathrm{~d}$ before parturition and continued until $4 \mathrm{~h}$ postcalving in both groups of cows. However, this drop in serum calcium was more pronounced in TRT cows (Figure 1B). Total colostrum amounts were the same for the pre- and postcalving milking (5.9 \pm 0.8 vs. $8.2 \pm 1.1 \mathrm{~kg}$ respectively; $P=$ $0.12)$. Serotonin and total calcium concentrations were greater in colostrum from cows that were milked for the first time before calving (TRT; milking 1 - precalving) compared with the cows that were milked for the first 
time postcalving (CON; milking 1 - postcalving; $P<$ $0.05)$ and compared with the TRT cows second milking (TRT; milking 2 - postcalving; $P<0.048$; Figure $2 \mathrm{~A}$ and B). Calves born to TRT cows had increased circulating 5 -HT concentrations compared with the CON calves $(3,676 \pm 747$ and $14,202 \pm 3,382 \mathrm{ng} / \mathrm{mL}$ for CON and TRT, respectively; $P=0.007$; Figure $2 \mathrm{C}$ ). Serum 5-HT and calcium concentrations were negatively correlated $(\mathrm{r}=-0.57, \mathrm{n}=130 ; P=0.04)$ for the CON cows and serum 5-HT and calcium concentrations were positively correlated ( $\mathrm{r}=0.6, \mathrm{n}=169 ; P=0.02)$ for the TRT cows. In the present study, cows milked $1 \mathrm{~d}$ precalving had lower serum 5-HT and calcium concentrations and a more pronounced drop in calcium concentrations compared with cows only milked after calving. The similar decrease observed for serum 5-HT and calcium concentrations in the TRT cows was opposite to what occurred in CON cows. Precalving milking affected not only colostrum total calcium and 5-HT concentrations, but also 5-HT concentrations in the calves.

The endocrine and paracrine environment, together with the rate of milk removal, ultimately affect the functionality of mammary epithelial cells (MEC). Serotonin, which is produced locally by MEC, regulates milk

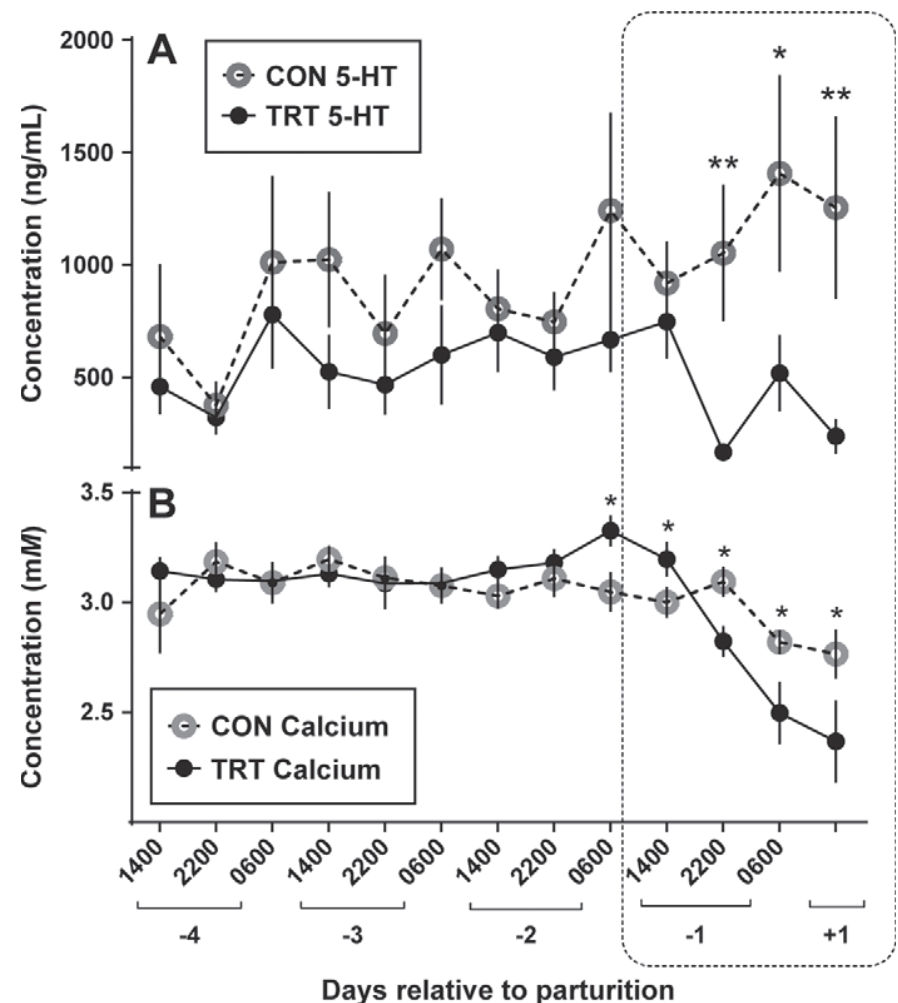

Figure 1. Least squares means of maternal serum serotonin (5-HT; A) and ionized calcium concentrations (B) in cows milked for the first time the day ( $-1 \mathrm{~d}$ relative to parturition) before calving (TRT; $\mathrm{n}=$ 13) versus cows milked for the first time $4 \mathrm{~h}(+1 \mathrm{~d}$ relative to parturition) after calving $(\mathrm{CON} ; \mathrm{n}=10)$. ${ }^{*} P<0.01 ; * * P<0.001$. secretion in an autocrine-paracrine fashion, and it may affect milk composition (Matsuda et al., 2004; Collier et al., 2012). Milk accumulation in the gland can cause increased 5-HT concentrations. High concentrations of 5-HT can exert an inhibitory signal to MEC inhibiting milk protein synthesis and cause MEC apoptosis (Matsuda et al., 2004). Additional research indicated that 5-HT influences tight junction permeability in a biphasic manner, initially, with increasing concentrations of 5-HT decreasing tight junction permeability and with further increases in 5-HT concentrations increasing tight junction permeability (Stull et al., 2007; Pai and Horseman, 2008). Intramammary administration of a selective 5-HT reuptake inhibitor increased 5-HT levels, decreased milk yield, and compromised tight junction permeability in dairy cows (Hernandez et al., 2011); this was also shown in humans and mice (Marshall et al., 2010).

It is possible that initiating milking precalving could enable the removal of the 5-HT inhibitory signal at the same time that milk synthesis is being increased in the MEC precalving. Cows initiate lactogenesis before calving, whereas in humans it is initiated approximately 2 d after parturition (Neville and Morton, 2001). In addition to the effects of precalving milking on circulating 5-HT concentrations, we saw significant effects on circulating calcium concentrations in the cows as well. Specifically, the observed decrease in 5-HT, in cows milked precalving, was accompanied by a decrease in calcium concentrations. We have previously demonstrated that circulating 5-HT concentrations are positively correlated with circulating concentrations of calcium in dairy cattle (Laporta et al., 2013c).

We suspect that milking precalving could be removing 5-HT that has accumulated in the mammary gland before parturition and that a small amount of 5-HT could be transferred to the calf via the colostrum. Additionally, we saw significant changes in total calcium concentrations in the colostrum, which we believe could be in due in part to changes observed in circulating 5-HT concentrations (Laporta et al., 2013c; Horseman and Hernandez, 2014). Furthermore, removal of accumulated 5-HT in the mammary gland precalving could be of importance to the subsequent lactation of the cow. Milking precalving could also affect 5-HT synthesis within the mammary gland and therefore affect maternal 5-HT and calcium concentrations, as well as affect 5-HT transfer via the placenta to the calf before parturition; however, we did not investigate this possibility in this experiment. Maternal transfer of 5-HT during gestation has been demonstrated in mice and humans (Noorlander et al., 2008). Further investigation of how precalving milking may affect mammary gland and circulating 5-HT concentrations is needed. 

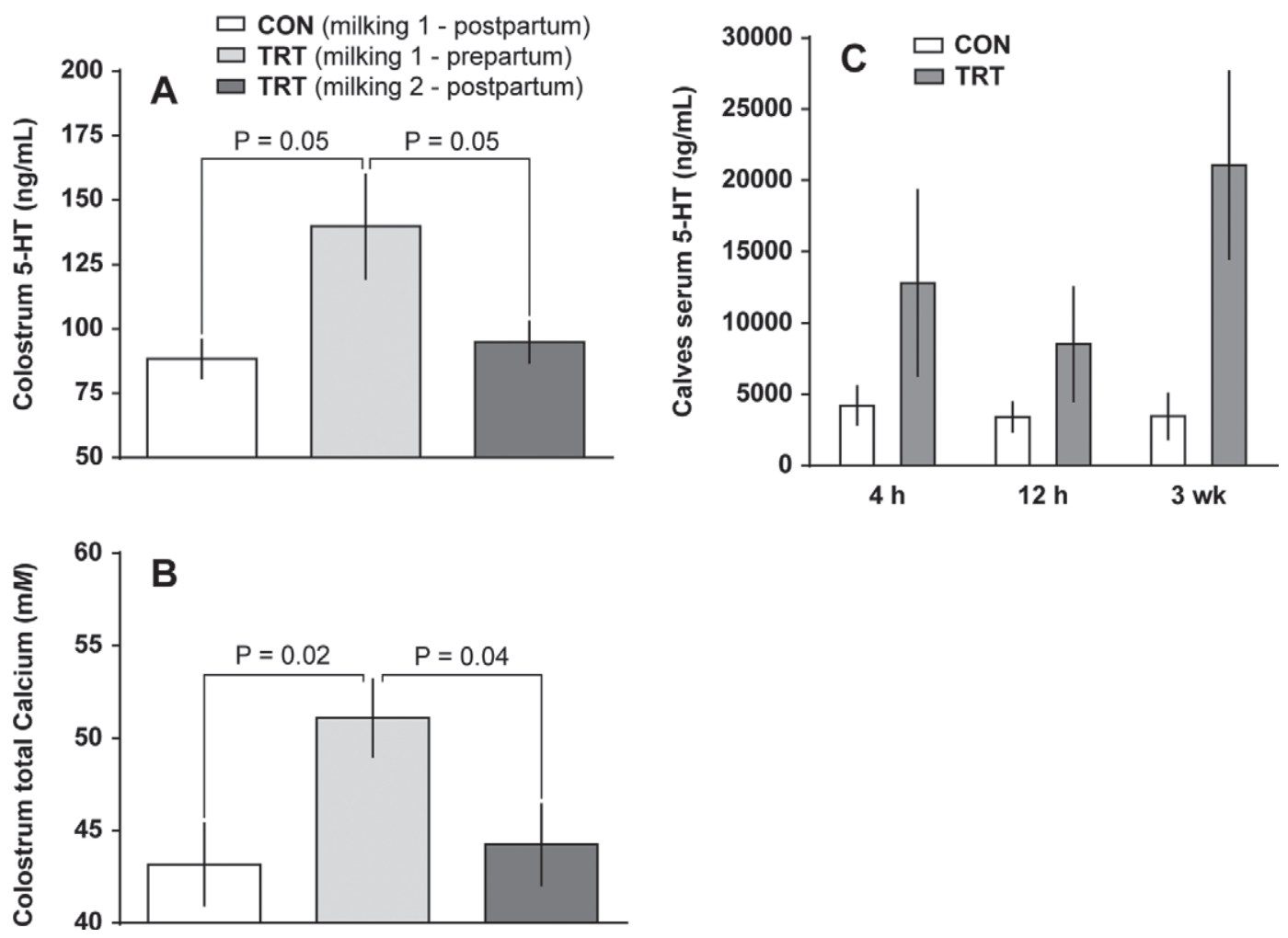

Figure 2. Least squares means of serotonin (5-HT; A) and total calcium (B) concentrations in the colostrum collected from cows $(\mathrm{n}=13)$ milked for the first time the day before calving (TRT; milking 1 - precalving) and then milked again $4 \mathrm{~h}$ after calving (TRT; milking 2 - postcalving), and from cows milked for the first time $4 \mathrm{~h}$ after calving (CON; milking 1 - postcalving; $\mathrm{n}=10)$. (C) Serotonin concentrations in serum collected from calves born to TRT or CON cows collected at 4 and $12 \mathrm{~h}$, and 3 wk after birth.

In addition to the observations of changes in circulating 5-HT in the cows, calves, and colostrum, relative to timing of first milking, we showed for the first time that calves overall have higher circulating concentrations of 5-HT compared with mature lactating cows. Given that the gut produces the majority of the 5-HT in the body, this observation could be due to the fact that calves are preruminants, and have a similar digestive system to monogastric animals (Swanson and Harris, 1958). However, in this experiment, we did not test whether 5 -HT concentrations remained elevated after $3 \mathrm{wk}$ of age, therefore we do not know what the implications of this observation are. The difference in serum 5-HT concentrations in the calf cannot be only attributable to 5-HT in colostrum; therefore, it is more than likely that other pathways or mechanisms are contributing to this observation, including 5-HT synthesis in the gut. In the cow, it appears timing of first milking has a direct effect on the mammary gland itself, as well as an effect on calf serum 5-HT concentrations. It appears that precalving milking enhances the transfer of 5 -HT from the maternal circulation to the colostrum, as we have previously been unable to detect 5-HT in mature milk; however, what the physiological importance is remains unknown (data unpublished). We are unable to determine the source or sources of increased 5-HT concentrations in the calves born to TRT cows compared with CON cows; however, it is likely that several contributors exist, which are not limited to the mammary gland or placenta, including the gut.

Presence of 5-HT in colostrum could potentially be important to the calf; however, we have not performed experiments investigating this possibility or the exact physiological relevance. Research indicates that 5-HT is involved in the regulation of gastrointestinal activity and bowel development in offspring (Côté et al., 2007). This may be of particular importance for cattle, as they born as preruminants (Swanson and Harris, 1958). Furthermore, 5-HT is a known regulator of immunity (Mössner and Lesch, 1998). Additionally, we saw significant changes in milk calcium in TRT cows, which may in part be due to changes in 5-HT concentrations (Laporta et al., 2013a; Kronqvist et al., 2014).

In summary, our data show that precalving milking significantly affects both cow and calf circulating 5 -HT concentrations, cow circulating calcium concentrations, as well as colostrum 5-HT and total calcium concentrations. Further research should be conducted in an 
attempt to separate the roles of circulating 5-HT from that produced within the mammary gland, as well as the specific effects and sources of 5 -HT on the calf. Detailed and specific follow-up studies in ruminants are required to assess the extent of 5 -HT placental transfer and its role on pre- and postnatal development and the long-term effects on calf health.

\section{REFERENCES}

Berger, M., J. A. Gray, and B. L. Roth. 2009. The expanded biology of serotonin. Annu. Rev. Med. 60:355-366.

Bowers, S., S. Gandy, K. Graves, S. Eicher, and S. Willard. 2006. Effects of precalving milking on postcalving reproduction, udder health and production performance in first-calf dairy heifers. J. Dairy Res. 73:257-263.

Collier, R. J., L. L. Hernandez, and N. D. Horseman. 2012. Serotonin as a homeostatic regulator of lactation. Domest. Anim. Endocrinol. 43:161-170.

Côté, F., C. Fligny, E. Bayard, J. M. Launay, M. D. Gershon, J. Mallet, and G. Vodjdani. 2007. Maternal serotonin is crucial for murine embryonic development. Proc. Natl. Acad. Sci. USA 104:329-334.

Hannon, J., and D. Hoyer. 2008. Molecular biology of 5-HT receptors. Behav. Brain Res. 195:198-213.

Hernandez, L. L., J. L. Collier, A. J. Vomachka, R. J. Collier, and N. D. Horseman. 2011. Suppression of lactation and acceleration of involution in the bovine mammary gland by a selective serotonin reuptake inhibitor. J. Endocrinol. 209:45-54.

Hernandez, L. L., K. A. Gregerson, and N. D. Horseman. 2012. Mammary gland serotonin regulates parathyroid hormone-related protein and other bone-related signals. Am. J. Physiol. Endocrinol. Metab. 302:E1009-E1015.

Hernandez, L. L., S. W. Limesand, J. L. Collier, N. D. Horseman, and R. J. Collier. 2009. The bovine mammary gland expresses multiple functional isoforms of serotonin receptors. J. Endocrinol. 203:123-131

Horseman, N. D., and L. L. Hernandez. 2014. New concepts of breast cell communication to bone. Trends Endocrinol. Metab. 25:34-41.

Kronqvist, C., S. Ferneborg, U. Emanuelson, and K. Holtenius. 2014. Effects of pre-partum milking of dairy cows on calcium metabolism at start of milking and at calving. J. Anim. Physiol. Anim. Nutr. (Berl.) 98:191-196. http://dx.doi.org/10.1111/jpn.12038.

Laporta, J., T. L. Peters, S. R. Weaver, K. E. Merriman, and L. L. Hernandez. 2013a. Feeding 5-hydroxy-L-tryptophan during the transition from pregnancy to lactation increases calcium mobilization from bone in rats. Domest. Anim. Endocrinol. 44:176-184.

Laporta, J., T. L. Peters, K. E. Merriman, C. M. Vezina, and L. L. Hernandez. 2013b. Serotonin (5-HT) affects expression of liver metabolic enzymes and mammary gland glucose transporters during the transition from pregnancy to lactation. PLoS ONE 8:e57847.

Laporta, J., S. A. Moore, M. W. Peters, T. L. Peters, and L. L. Hernandez. 2013c. Short communication: Circulating serotonin (5HT) concentrations on day 1 of lactation as a potential predictor of transition-related disorders. J. Dairy Sci. 96:5146-5150.

Marshall, A. M., L. A. Nommsen-Rivers, L. L. Hernandez, K. G. Dewey, C. J. Chantry, K. A. Gregerson, and N. D. Horseman 2010. Serotonin transport and metabolism in the mammary gland modulates secretory activation and involution. J. Clin. Endocrinol. Metab. 95:837-846.

Matsuda, M., T. Imaoka, A. J. Vomachka, G. A. Gudelsky, Z. Hou, M. Mistry, J. P. Bailey, K. M. Nieport, D. J. Walther, M. Bader, and N. D. Horseman. 2004. Serotonin regulates mammary gland development via an autocrine-paracrine loop. Dev. Cell 6:193-203.

Mössner, R., and K. P. Lesch. 1998. Role of serotonin in the immune system and in neuroimmune interactions. Brain Behav. Immun. $12: 249-271$.

Neville, M. C., and J. Morton. 2001. Physiology and endocrine changes underlying human lactogenesis II. J. Nutr. 131:3005S-3008S.

Noorlander, C. W., F. F. T. Ververs, P. G. J. Nikkels, C. J. A. van Echteld, G. H. A. Visser, and M. P. Smidt. 2008. Modulation of serotonin transporter function during fetal development causes dilated heart cardiomyopathy and lifelong behavioral abnormalities. PLoS ONE 3:e2782.

Pai, V. P., and N. D. Horseman. 2008. Biphasic regulation of mammary epithelial resistance by serotonin through activation of multiple pathways. J. Biol. Chem. 283:30901-30910.

Rastani, R. R., N. S. Del Rio, T. F. Gressley, G. E. Dahl, and R. R. Grummer. 2007. Effects of increasing milking frequency during the last 28 days of gestation on milk production, dry matter intake, and energy balance in dairy cows. J. Dairy Sci. 90:1729-1739.

Rortvedt, L. A., and T. D. Crenshaw. 2012. Expression of kyphosis in young pigs is induced by a reduction of supplemental vitamin D in maternal diets and vitamin $\mathrm{D}, \mathrm{Ca}$, and $\mathrm{P}$ concentrations in nursery diets. J. Anim. Sci. 90:4905-4915.

Stull, M. A., V. Pai, A. J. Vomachka, A. M. Marshall, G. A. Jacob, and N. D. Horseman. 2007. Mammary gland homeostasis employs serotonergic regulation of epithelial tight junctions. Proc. Natl. Acad. Sci. USA 104:16708-16713.

Swanson, E. W., and J. D. Harris. 1958. Development of rumination in the young calf. J. Dairy Sci. 12:1768-1776. 